\title{
21
}

\section{Update on EPA's Urban Watershed Management Branch Modeling Activities}

Richard N. Koustas

The Environmental Protection Agency (EPA) Office of Research and Development (ORD) Urban Watershed Management Branch (UWMB) has identified an approach for urban modeling research that includes two major objectives: to develop a standard operating procedure for the user community and to develop a BASINS-compatible Stormwater Management Model (SWMM) - Geographical Information System (GIS) interface. To achieve this, UWMB is currently involved with several stormwater modeling projects. This chapter provides the SWMM-user community with a description of the UWMB approach to urban watershed modeling research and provides an update on current ORD SWMMrelated projects.

\subsection{Introduction}

The original EPA SWMM, one of the first computer-based runoff models, was funded by the EPA and released in 1971. It was written in Fortran and ran on mainframe computers. Several major improvements have been made since then including: version 2 was released in 1975, EXTRAN module was added by Camp Dresser McKee (CDM) in 1977, version 4 was released in 1988 and EPA released Windows SWMM in 1994 to assist in TMDLanalysis. The current EPA-supported

Koustas, R. 2000. "Update on EPA'S Urban Watershed Management Branch Modeling Activities." Journal of Water Management Modeling R206-21. doi: 10.14796/JWMM.R206-21.

(C) CHI 2000 www.chijournal.org ISSN: 2292-6062 (Formerly in Applied Modeling of Urban Water Systems. ISBN: 0-9683681-3-1) 
SWMM, version 4.3, (Ed. note:written September 1999) is DOS based (Huber 1988, Roesner, et. al, 1988). The EPA did not actively support SWMM during most of the 80 's, but the model became self-sustaining by outside interest. Most notable refinements include the addition of Graphical User Interfaces (GUI), such as XP-SWMM and PCSWMM. Model work was beginning to develop in Europe, such as Hydroworks, from Wallingford Software in Great Britain, and MikeSWMM / MOUSE GIS from the Danish Hydraulic Institute (DHI) and CDM. Many model modifications exist, such as UD-SWMM, modified by the Urban Drainage and Flood Control District of Denver, Colorado.

Other hydrologic models that were developed during this time include the Army Corps of Engineers (COE) Hydrologic Engineering Center models HEC1, HEC-2. These evolved into HEC-HMS and HEC-RAS and are still widely used.

UWMB held a three-day stormwater modeling workshop in Edison, New Jersey in October 1997. Participants included representatives from other EPA organizations, other Federal agencies doing related work, the private sector, and academia. Presentations were made on many aspects of urban watershed modeling. Based on this workshop, UWMB drafted a white paper mapping out a five-year research plan (USEPA 1998). The white paper, entitled $A$ Research Direction for Urban Watershed Modeling, describes how UWMB would focus research activities to be most beneficial to the interested parties. The paper outlines UWMB's two major objectives as

1. developing standard operating procedures to help assure the user community will efficiently collect the correct information, adopt standard quality assurance and quality control procedures, and store information in a uniform data format, and

2. to develop a Better Assessment Science Integrating Point and Nonpoint Sources(BASINS)-compatible interface between SWMM and a GIS.

\subsection{Approach}

Influential factors used to develop the research direction as outlined in the white paper were: a push toward community based environmental protection, responsibility for wet weather flow management being transferred to local government officials, renewed Federal funding for SWMM development, increased desktop computer power, and the organizational changes within EPA ORD.

UWMB has developed partnerships with the EPA's Office of Water (OW) and with the Army Corps of Engineers (COE). UWMB and OW have similar interests in watershed modeling. The COE has existing models that predict scour and sediment deposition in large streams and rivers. EPA would like to adapt those models to smaller streams and use them to predict stream impacts with local development or best management practice (BMP) implementation. 


\subsubsection{ORD Projects}

ORD has four ongoing SWMM-related research projects. The first two are in cooperation with the EPA Office of Wastewater Management (OWM), OW. Table 21.1 provides a brief description of each of these projects.

Table 21.1 Ongoing ORD SWMM-Related Projects.

\begin{tabular}{lll}
\multicolumn{1}{c}{ Short Title } & \multicolumn{1}{c}{ Responsible Organization } & \multicolumn{1}{c}{ Description } \\
\hline $\begin{array}{l}\text { SWMM } \\
\text { Upgrade }\end{array}$ & $\begin{array}{l}\text { Oregon State University } \\
\text { Civil, Construction, and } \\
\text { Environmental Engineering } \\
\text { PI: Wayne C. Huber } \\
\text { Date: Nov. 1997 - Dec. 1999 }\end{array}$ & $\begin{array}{l}\text { Evaluate/Improve SWMM Modeling } \\
\text { Techniques for Stormwater Sanitary Sewer } \\
\text { Overflow, and Combined Sewer Overflow } \\
\text { Management }\end{array}$ \\
$\begin{array}{lll}\text { SWMM/GIS } \\
\text { Report }\end{array}$ & $\begin{array}{l}\text { University of Colorado } \\
\text { PI: James Heaney }\end{array}$ & $\begin{array}{l}\text { An EPA Report on Geographical Information } \\
\text { Systems and Urban Stormwater Management }\end{array}$ \\
$\begin{array}{l}\text { Nov. 1997-Feb. 1999 } \\
\text { Interface }\end{array}$ & $\begin{array}{l}\text { Lockheed Martin Information } \\
\text { Systems (LMIS) }\end{array}$ & $\begin{array}{l}\text { Develop a BASINS-compatible SWMM -GIS } \\
\text { interface }\end{array}$ \\
$\begin{array}{l}\text { Erosion-Scour } \\
\text { Deposition }\end{array}$ & US Army Corps of Engineers & $\begin{array}{l}\text { Adapting the COE's Erosion - Scour - } \\
\text { Deposition modeling to predict scour and } \\
\text { deposition in smaller streams/urban setting }\end{array}$ \\
\hline
\end{tabular}

\subsection{SWMM Upgrade}

EPA SWMM version 4.3 is available for downloading from the EPA File Transfer Protocol(FTP) internet site at ftp://ftp.epa.gov/epa_ceam/wwwhtml/swmm.htm. A beta version of SWMM 4.4, that was developed without EPA funding, is available through the Oregon State internet site www.ccee.orst.edu/swmm.htm and includes enhancements provided by CDM. The SWMM improvement project is being conducted by Huber (Oregon State). The primary purpose is to upgrade the SWMM code, correct known errors, maintain currency, and add selected improvements (such as enhancing BMPs options and adding X-Y coordinates for plotting). The project also includes updating the User's Guide and program documentation. The completion date for this project, including documentation, is December 1999 and is scheduled to undergo peer review in 2000.

\subsubsection{Overall Goal}

This project strengthens the SWMM engine while providing for improvements related to modern computer technology (e.g. GIS linkage, GUI development), and to update the user documentation. Most improvements and upgrades will be to the code with limited changes to the user interface. 


\subsubsection{Needed SWMM Engine Improvements}

The following is a list of useful improvements that could be made to the SWMM Fortran engine including suggestions that have been taken from SWMM-USERS forum discussions on the University of Guelph list server:

General maintenance, cleanup and minor improvements.

- Rewrite users' manuals.

- Provide minimal GUI. Link with databases, GIS, EPA BASINS, time series managers.

- Link with other models and other SWMM software.

- Provide linkages for other models.

- Incorporate knowledge-base/databases of BMP performance and other quality data.

- Infiltration/inflow (I/I), exfiltration, and sanitary sewer overflow (SSO) problems.

- Include $x-y$ coordinates for plotting.

Rain and Statistics Blocks

- Merge rainfall and runoff event row

- Add more conventional statistics.

Runoff Block

- Include soil storage cutoff, as in SCS method.

- Added hydrology/hydraulic options, e.g., kinematic wave, exfiltration, cascading planes.

- Include more general urban water balance parameters, especially irrigation.

- Improve/expand quality routines. Enhance BMP options and data.

- Improve erosion and solids routines.

Transport and/or Extran Blocks

- Provide improved solids simulation (Transport). Link with S/T Block. Include changes in sewer cross sections. Link hydraulics to stream morphology and channel cross section.

- Include local losses (e.g., k-values for head losses) as user option.

- Allow regulator settings to change depending on downstream conditions and timed changes.

- Overall, provide better real time control (RTC) options.

- Add additional pipe types and hydraulic structures.

- Allow a variable time step or simplified routing during storm interevent interval to decrease simulation times. Work toward more general ability to use Extran for continuous simulation, including the possibility of changing numerical solution method. 


\section{Storage/Treatment Block}

- Explicit inclusion of wetland removal processes (and/or in Transport).

- Link solids removal with $\mathbb{I} / O$ from/to other blocks.

Particular emphasis is being placed on overland flow and riparian BMP options that are currently difficult to simulate with the current version of EPA SWMM. Some improvements that are already in SWMM version 4.4 beta are also being incorporated and the updated EPA SWMM will be peer reviewed.

\subsubsection{Specific Project Tasks}

The initial task was to identify and prioritize the needed or recommend improvements. Digital Visual Fortran (DVF, but now sold as Compaq Visual Fortran) was selected over Fortran 90 and the Lahey Fortran as the compiler. A literature review of vegetative pollutant removal in overland flow and riparian zone areas has been completed and a student project report will augment this review. Oregon State will incorporate some of the CDM changes into the EPA SWMM upgrade and the SWMM User's manual will be rewritten. The updated code will be peer reviewed in accordance with EPA guidance (USEPA 1994).

\subsubsection{Special Cooperation}

Although the primary researcher on this project is Huber, several other organizations have been beneficial. The SWMM-Users List is monitored continuously for improvement ideas. A parallel project at the University of Colorado is contributing to GIS and water balance efforts (Heaney 1999a). CDM has been generous with providing code changes already implemented in version 4.4 beta. Some code changes from XP-SWMM are also to be included. Model improvements by Reid Crowther Engineers with SewerCad and Extran may also be used. The Software Engineering Institute (SEI) at Carnegie Mellon University has contributed ideas on model structure.

\subsubsection{Summary}

This project is intended to maintain SWMM's prominence as the leading comprehensive urban runoff model in use today. The success of the project lies in large part upon the cooperation of several groups and the many individuals within the SWMM user community. 


\subsection{SWMM-GIS report}

An urban watershed model requires extensive data about the complexity of surfaces, flow paths and conduits found in developed areas. Some geographic data, such as geographic boundaries of the catchment are used as boundary conditions for the model. Therefore, integrating GIS and stormwater modeling would be very beneficial.

The SWMM-GIS project is being conducted by Heaney of the University of Colorado. The primary purpose is to provide a report that evaluates how GIS can be used to evaluate urban stormwater problems including urban stormwater management models. The project is scheduled for completion in February 1999.

\subsubsection{Overall Goal}

The primary goal of this project is to evaluate how GIS and SWMM can be used to evaluate urban stormwater problems.

\subsubsection{Specific Tasks}

The first task in this project was to conduct a literature search to find GIS used with urban watershed modeling. Over 50 documents were found and categorized into the following groups: urban drainage models pre-processor, post-processor for urban stormwater models, estimate spatial input parameters estimations and non-point source pollutant loads estimates. The following list is a sample of the documents that were identified in the literature search and is not meant to be all inclusive.

Model pre-processor:

- Pryl et al. (1998)

- Rodriguez et al. (1998)

- Sotic et al. (1998)

Post-processor for urban stormwater models:

- Xu et al. (1998)

- Sorensen (1996)

- Shamsi (1998)

Spatial input parameters estimation:

- Olivera et al. (1996)

- Cluis et al. (1996)

- Mercado (1996)

- Herath et al. (1996)

- Olivera et al. (1998)

GIS used to estimate non-point source pollutant loads:

- Wright et al. (1995) 
- Battin et al. (1998)

- Olivera et al. (1996)

- Scarboroough and Yetter (1998)

Integration of GIS and hydrologic time series

- Pryl et al. (1998)

- Rodriguez et al. (1998)

- Barbe (1993)

- Sorensen et al. (1996)

- Stotic et al. (1998)

Integration of GIS and urban stormwater models

- Charnock et al. (1996)

- Kopp (1996)

- Sponemann et al. (1996)

- Shamsi (1998)

- Shamsi (1997)

Management evaluation using integrated GIS and urban stormwater models

- Rodriguez et al. (1998)

- Tskhai et al. (1995)

- Makropoulos et al. (1998)

- Mark et al. (1997)

The second task is to evaluate the use of GIS for evaluating source controls for urban wet weather flows (WWFs). Traditional urban WWF management relied on downstream controls, however there is increasing interest in controlling storm runoff at the source. Neighborhoods are designed to contain runoff from nearly all small storms (DER, 1997). Many municipalities have developed GIS data down to the parcel level. Under this task, it will be investigated whether GIS at that level may be used by SWMM to model runoff assisting on-site storage design.

To illustrate how GIS can be used on a micro level, finding a locality with existing data is necessary. The City of Aurora, Colorado was selected. Available themes for the municipality include: water lines, digital elevation models, rain gages, stream gages, parcels, sewer lines, manholes, etc. There are many tables for each theme. Using the relational database capabilities of ArcView, complex queries and easy export to spreadsheet programs can be performed.

The City of Aurora, Colorado was also used to demonstrate GIS/SWMM linkages on a test urban area. A conventional stormwater system (without GIS) will be designed. The same system will be designed using the available GIS data and SWMM. The results will be linked to a spreadsheet drainage hydrology model to evaluate the use of the combination in major, minor, and micro storms. The micro-storm analysis will be used as a tool to assist in the evaluation of possible BMP selection and implementation. This will be done with two other research 
projects using the Boulder neighborhood: Optimal Stormwater Design from Many Alternatives (Heaney, et. al., 1998b) and Methods for Evaluating Cost of Urban Stormwater Systems (Heaney et al., 1998c)

\subsection{Develop SWMM Link to BASINS}

Urban and urban fringe communities can contribute a substantial load to the watershed and degrade receiving water quality for combined and separate sewer systems. Therefore, several EPA program offices may potentially gain by linking the SWMM model to BASINS. This link would be a valuable tool for urban planners and watershed managers to evaluate the urban load in relation to other loads in the watershed and provide a more holistic view to watershed management. This project is being done through an EPA Office of Administration and Resources Management (OARM) contract with Lockheed Martin Information Services (LMIS). The estimated completion date is the first quarter 2000.

\subsubsection{Objectives}

The objective of this project is to link the SWMM model with the BASINS model family. The existing SWMM model will be prepared to interface with BASINS. In addition, GIS databases will be shared and maintained (EPA 1998).

\subsubsection{Approach}

This project has been divided into various related tasks. These tasks are designed to make all datasets compatible, develop the linkage, and to verify the results. The first task is to identify the SWMM input variables as either critical or noncritical. This variable list will then be expanded to identify georeferenced information, constants, identify seasonally variable parameters, and give 'reasonable ranges' for the parameters.

The format of the meteorological data used by SWMM and BASINS are incompatible. SWMM uses MET files and BASINS uses WDM data files. This task is to automate preparation of SWMM meteorological files from pluviometer data. The specific task will be to convert rain gage (pluviometer) data and BASINS WDM data files into SWMM MET files automatically.

The next task is to develop examples of required GIS themes with attribute tables in ArcView in an urban environment. During this development, all data will be georeferenced in separate thematic overlays. Then, using existing data, the contractor will develop ArcView themes and create SWMM data input files. The final task will be to debug the developed interface. 


\subsubsection{Status}

The contract for this project has only recently been awarded. As work progresses, updates will be posted on the UWMB internet site (www.epa.gov/ ednnrmrl/).

\subsection{Erosion - Scour Deposition}

The Erosion-Scour Deposition project is a three-year project with the Army Corps of Engineers (COE) Waterways Experiment Station (WES) in Vicksburg, Mississippi. WES will develop a numerical model that will predict change in stream channels from land use changes. Land use changes alter stormwater runoff upsetting the established stream equilibrium. Streambed scour and erosion alter the stream morphology to reestablish the equilibrium. To assist community decision makers in watershed planning decisions, this model will be developed to predict stream changes based on planned development and land use changes. The model will include predictions when the altered hydrology will disrupt the benthic communities.

Excessive sedimentations and accelerated geomorphic changes are direct results of land use charges. This can be generalized as a change in the natural storage of a watershed (McCuen 1979). WES has developed models that predict bank erosion, bottom scour, and the location of sediment deposition in large rivers. WES will modify the existing models to make it applicable to low-order streams under adverse wet-weather flow conditions.

\subsubsection{Objective}

The objective of this project is to develop user-friendly computer modules to estimate long-term changes in stormwater runoff volume, channel shear stress, stream power, and channel morphology. These modules will blend with existing watershed management models.

\subsubsection{Approach}

WES will develop a package of watershed modeling modules that use BASINS, SWMM and GIS products. Analysis and visual output will be customized in ESRI Avenue to streamline model use. The project will be conducted in two major phases: model development and model verification.

During the model development phase, WES will develop hydrology, hydraulic and bioassessment modules. These modules will help predict long term hydrographs of various land use scenarios, distribution of stream power and 
shear stress over time, duration curves, and channel enlargement. The second phase of the project is to demonstrate the numerical model comparing and validating EPA data and the watershed model.

\subsubsection{Status}

The work on this project is just getting under way. As results become available, they will be posted on the UWMB home page at www.epa.gov/ednnrmrl/.

\subsection{Conclusion}

UWMB has identified an approach for urban modeling research. The two pronged approach includes the development of a standard operating procedure for the user community and the development a BASINS-compatible SWMM - GIS interface. Due to a reorganization within ORD and renewed Federal funding for SWMM, UWMB is currently involved with several stormwater modeling projects. The SWMM Upgrade will be the first version of EPA SWMM that will undergo a formal peer review. The SWMM GIS report will summarize how GIS can be used with SWMM to assist in stormwater management design. The SWMM BASINS linkage will provide an EPA tool that ties BASINS GIS with a run off model. And a COE scour and deposition model will be adapted to handle urban development and smaller streams.

\section{References}

Barbe, D.E., Miller, H., and Jalla, S. (1993) Development of a computer interface among GDS, SCADA and SWMM for use in urban runoff simulation. In Harlin, J. M, and Lanfear, K.J. (eds.) Proc. Of the Symposium on Geographic Information Systems and Water Resources. American Water Resources Association, Bethesda, MD. P. 113-120.

Battin, A., Kinerson, R., and Lahlou, M. (1998) EPA's Better Assessment Science Integrating Point and Nonpoint Sources (BASINS) - A Powerful Tool for Managing Watersheds. Internet file retrieved 11/6/98 from the Center for Research in Water Resources, The University of Texas at Austin. http://www.crwr.utexas.edu/ gis/gishyd98/epa/battin/p447.htm

Charnock, T.W., Hedges, P.D., and Elgy, J. (1996) Linking multiple process models with GIS. In Kovar, K., and Nachtnebel, H.P. (Eds.) HydroGIS '96: Application of Geographic Information Systems in Hydrology and Water Resources Management. International Association of Hydrologic Sciences Publication No. 235. IAHS Press, Wallingford, UK. P. 29-36. 
Cluis, D., Martz, L., Quentin, E., and Rechatin, C. (1996) Coupling GIS and DEM to classify the Hortonian pathways of non-point sources to the hydrologic network. In Kovar, K., and Nachtnebel, H.P. (eds.) HydroGIS'96: Application of Geographic Information Systems in Hydrology and Water Resources Management. International Association of Hydrologic Sciences Publication No. 235. IAHS Press, Wallingford, UK. P. 37-44.

da Costa, J.R., Lacerda, M., and Jesus, H.B. (1995) The Portuguese Water Resources Information System: using OOP to integrate time series and GIS. Proc. Of 1995 ESRI User Conference. Internet file retrieved from http://www.esri.com/library/userconf/ proc $95 /$ to $300 / \mathrm{p} 296 . \mathrm{html}$

da Costa, J.R., Jesus, H.B., and Lacerida, M. (1996) Integrating GIS and time series analysis for water resources management in Portugal. In Kovar, K., and Nachtnebel, H.P. (Eds.) HydroGIS'96: Application of Geographic Information Systems in Hydrology and Water Resources Management. International Association of Hydrologic Sciences Publication No. 235. IAHS Press, Wallingford, UK. P. 289-297.

Department of Environmental Resources, Prince George's County, MD, (1997) Lowimpact Development Design Manual Rev 112597

Heaney, J.P., Sample, D., and Wright, L. (1999a) Geographical Information Systems and Urban Stormwater Management, Draft report to the US EPA, Edison, NJ.

Heaney, J.P., Sample, D., and Wright, L. (1999b) Innovative Methods for Optimization of Urban Stormwater Systems, Final report to the US EPA, Edison, NJ.

Heaney, J.P., Sample, D., and Wright, L. (1999c) Costs of Urban Stormwater Systems, Final report to the US EPA, Edison, NJ.

Herath, S., Musiake, K., and Hironaka, S. (1996) Development and application of a GIS based distributed catchment model for urban areas. In Seiker, F., and Verworn, H.R. (eds.) IAHR/IAWQ Pro. Of the $7^{\text {th }}$ Annual Conf. On Urban Storm Drainage. Hannover, Germany. Vols. III, p. 1695-1700.

Huber, W.C. and R.E. Dickinson, Storm Water Management Model User's Manual, Version 4, EPA/600/3-88/001a (NTIS PB88-236641/AS), Environmental Protection Agency, Athens, GA, 1988.

Kopp, S.M. (1996) Linking GIS and hydrologic models: where have we been, where are we going? In Kovar, K., and Nachtnebel, H.P. (eds.) HydroGIS'96: Application of Geographic Information Systems in Hydrology and Water Resources Management. International Association of Hydrologic Sciences Publication No. 235. IAHS Press, Wallingford, UK. P. 133-139.

Makropoulos, C., Butler, D., and Maksimovic, C. (1998) A GIS based methodology for the evaluation of suitability of urban areas for source control application. In Butler, D. and Maksimovic, C. (eds.) UDM'98 Fourth International Conf. On Developments in Urban Drainage Modeling. Imperial College of Science, Technology \& Medicine, London, UK. P. 59-66.

Mark, O., van Kalken' T., Rabbi, K., and Kjelds, J. (1997) A Mouse GIS study of the drainage in Dhaka City. Proc. Of the 1997 ESRI User Conference. Internet file retrieved from http://www.esri.com/library/userconf/proc97/PROC97/TO500/ PAP487/P487.HTM

McCuen, R.H. (1979) Down stream effects of stomsater management basisns. Journal of Hydraulics Division, ASCE 105(HY11) p. 1343-46

Mercado, R.M. (1996) Geographic information systems (GIS) and image processing for 
stormwater management modeling using XPSWMM in Tallahassee, Florida. In Hallam, C.A., Salisbury, J.M., Lanfear, K.J., and Battaglin, W.A. (Eds.) Proc. Of the AWRA Annual Symposium: GIS and Water Resources. American Water Resources Association, Herndon, VA. P. 305-313.

Olivera, F., Maidment, D.R., and Charbeneau, R.J. (1996) Spatially Distributed Modeling of Storm Runoff and Non-Point Source Pollution Using Geographic Information Systems (GIS). CRWR Online Report 96-4. Internet file retrieved from The Center for Research in Water Resources, The University of Texas at Austin. Http://www.crwr.utexas.edu/gis/ gishyd98/library/olivera/ header.htm

Pryl, K., Vanecek, S., and Vasek, P. (1998) Data processing and manipulation tools used for urban drainage systems. In Butler, D. and Maksimovic, C. (eds.) UDM'98 Fourth International Conf. On Developments in Urban Drainage Modeling. Imperial College of Science, Technology \& Medicine, London, UK. P. 327-332.

Rodriguez, F., Andrieu, H., Creutin, J.D., and Raimbault, G. (1998) Relevance of geographic information systems for urban hydrological analysis. In Butler, D. and Maksimovic, C. (eds.) UDM'98 Fourth International Conf. On Developments in Urban Drainage Modeling. Imperial College of Science, Technology \& Medicine, London, UK. P. 333-340.

Roesner, L.A., Aldrich, J.A. and R.E. Dickinson, Storm Water Management Model User's Manual, Version 4: Addendum I, EXTRAN, EPA/600/3-88/001b (NTIS PB88236658/AS), Environmental Protection Agency, Athens, GA, 1988.

Scarborough, R.W., and Yetter, C.H. (1998) A case study evaluation of the ArcView/ Non-point source module interface in EPA's BASINS 2.0 watershed model. Internet file retrieved from the 1998 ESRI International User's Conference, http:/ www.esri.com/library/userconf/proc98/PROCEED/ABSTRACT/a247.HTM

Shamsi, U.M. 1998. "ArcView Applications in SWMM Modeling." Journal of Water Management Modeling R200-11. doi: 10.14796/JWMM.R200-11.

Shamsi, U.M. 1997. "SWMM Graphics." Journal of Water Management Modeling R195-07. doi: 10.14796/JWMM.R195-07.

Sorensen, H.R., Kjelds, J.T., Deckers, F., and Waardenburg, F. (1996) Application of GIS in hydrological and hydraulic modeling: DLIS and MIKE11-GIS. In Kovar, K., and Nachtnebel, H.P. (Eds.) HydroGIS'96: Application of Geographic Information Systems in Hydrology and Water Resources Management. Int. Assoc. of Hydrologic Sciences Pub. No. 235. IAHS Press, Wallingford, UK. p. 149-156.

Sotic, A., Despotovic, J., Petrovic, J., Babic, B., Djukie, A., and Prodanovioc, D. (1998) Hydro-informatic approach in sewer system design - Kumodraz case study. In Butler, D. and Maksimovic, C. (eds.) UDM'98 Fourth International Conf. On Developments in Urban Drainage Modeling. Imperial College of Science, Technology \& Medicine, London, UK. p.341-346.

Sponemann, P., Beeneken, L., Fuchs, L., Prodanovic, D., and Schneider, S. (1996) Criteria for geographic information systems used in urban drainage. In Seiker, F., and Verworn, H.R. (eds.) (1996) IAHR/IAWQ Proc. Of the $7^{\text {th }}$ Annual Conf. On Urban Storm Drainage. Hannover, Germany. Vols. III p. 1689-1694.

Tskhai, A., Shirokova, S., Konev, D., Koshelev, K., and Tskhai, T. (1995) GIS "hydromonitoring" and optimization model of enterprise water protection activity. 
In Simonovic, S., Kundzewicz, Z., Rosbjerg, D., and Takeuchi, K. (eds) Modeling and Management of Sustainable Basin-Scale Water Resource Systems. International Hydrologic Sciences Publication No. 231. IAHS Press, Wallingford, UK. p. 263-270.

USEPA (1994) Guidance for Conducting External Peer Review of Environmental Regulatory Models EPA 100-B-94-001, July 1994.

USEPA (1997) Better Assessement Science Integrating Point and Nonpoint Sources (BASINS), EPA -823-R-97-010. Office of Water.

USEPA (1998) A Research Direction for Urban Watershed Modeling, http:// www.epa.gov/ednnrmrl/projects/products/model.htm

Wright, L.T., S.J. Nix, J.M. Hassett and P.E. Moffa. 1995. "A Preliminary Urban Non-

Point Source Management Plan: A Modeling Approach." Journal of Water

Management Modeling R183-04. doi: 10.14796/JWMM.R183-04.

Xu, Z.X., Schultz, G.A., and Ito, K. (1998) GIS application in a watershed-based water resources management. In Butler, D. and Maksimovic, C. (eds.) UDM'98 Fourth International Conf. On Developments in Urban Drainage Modeling. Imperial College of Science, Technology \& Medicine, London, UK. p.487-494. 
